\title{
USING A REAL CONTRACT TO TEACH LAW HOLISTICALLY
}

Sinead J Eaton, School of Law, University of Limerick, Ireland

\section{$\underline{\text { Abstract }}$}

A globally used industry-standard contract proved to be of great use in teaching a few aspects of law and putting a few others in context. The practical exercise of analysing the provisions of an actual contract facilitated active learning. The use of contract provisions to manage risk and the use of standardised contracts to reduce legal costs and achieve efficiencies also emerged. Students learned about different aspects of law and the legislative process, as well as seeing how national legislation can come into being and how it can support, or fail to support, a particular business sector.

\section{Introduction}

There is an increased emphasis in Ireland on teaching law in a manner which explains its context to students and in a manner which involves an element of clinical legal education. All law students in my University spend approximately 6 months working with a law firm, or in a similar setting, as part of the degree programme. This happens during the students' third year. Final year law students at University of xxx also take "lawyering" modules where they work on projects in small groups and are guided by a member of faculty. The projects vary from studies of sentencing patterns in criminal cases to employment law clinics. Some of the projects are capable of being described as clinical legal education insofar as they involve live-client situations. Others are practical, involve looking at law in context and build on the 6 month clinical experience the students had. 


\section{Practice Report}

Having spent some time working in-house in the capital markets section of a bank, and using the International Swaps and Derivatives Association's (ISDA) pro forma master agreements, I decided to base my project on those. There are significant levels of commercial and financial activity in the financial products used to manage currency and interest rate risk. The high levels of risk management and investment by our banks with other financial institutions makes the area ripe for learning. Furthermore, all commercial lawyers have clients who avail of these risk management services provided by banks and other financial institutions. The group of students who selected this project above others were law students with an interest in securing professional traineeships in Ireland's top law firms and they had an interest in commercial law. Being able to outline to them the future relevance of this knowledge and learning helped to further arouse their interest, which assisted the learning greatly. ${ }^{1}$

The aim of the exercise was to allow the students engage in deep learning. This was achieved on the one hand by building on their previous study of contract law and also by taking them back to their earlier study of the stimuli for legislation and the varied purposes of, and motivations for, legislation on a particular aspect of law. These are what Ramsden describes as attributes of deep learning. ${ }^{2}$ While the final year students had studied contract law and the legislative process in previous years, the project

\footnotetext{
${ }^{1}$ Learning to teach in higher education, Ramsden, $2^{\text {nd }}$ ed. , Routledge Falmer, p.93

${ }^{2}$ Ibid. p.47
} 
drew those two modules together, added company law familiarity and gave them a holistic view of these areas of law. In many senses the exercise operated as a capstone module which wove together different strands of legal knowledge and 'placed' their knowledge in a real-world setting.

\section{Contract law in context}

\section{(i) Understanding the client's need for the financial transaction}

One of the reasons I chose the ISDA Master Agreement contract as a base for the project was that the Business School in University of Limerick has a replica trading floor and faculty with expertise in derivatives and similar financial products. The group of students who selected the ISDA Master Agreement project first attended a talk on the products typically traded under that master agreement, or contract. The students were introduced to over the counter (OTC) derivatives like interest rate swaps and foreign exchange products. The students learned how banks entered into those transactions with each other and how companies benefit from these risk management financial products. Our discussion after the seminar in the Business School revolved around purposes a commercial and corporate client might have for an interest rate swap or for foreign exchange products depending on their business. However, as the range of financial products is so wide and because they were new to the students, the next time I supervise the project I will provide notes on the financial products. Some of the students indicated in their feedback that this would be helpful. 


\section{Practice Report}

Attending the talk on the financial transactions/derivatives in the $x x x x x$ Business School's trading room meant the students had become operationally engaged. ${ }^{3}$ The students were pleased to see the replica trading floor and gain an understanding of the financial products traded between financial institutions as tools of diversification and management of risk. In addition, they learned how large trading companies manage their interest rate and currency exchange risks using these financial products.

That was the first step in the journey and showed the students what the subject matter of the contract would be.

\section{(ii) Understanding the merits of a master agreement}

The ISDA Master Agreement is one of many pro-forma and template documents produced by the Association for its members. The contracts between counterparties are built using a series of different documents. In the first instance there is the master agreement which contains definitions, events of default and representations. The documents were developed and adopted by the participants in this sector of financial activity. Various bank representatives and lawyers, both in-house and from firms, had combined their expertise to create the standard documents. That of course has the advantage of reducing legal costs for companies and financial institutions who use them. It also creates efficiencies due to the familiarity of all with the provisions of the standard form contracts.

\footnotetext{
${ }^{3}$ Engaging the curriculum in Higher Education, Barnett and Coate, The Society for Research into Higher Education and open University Press, p.138
} 


\section{Practice Report}

The second document which contributes to the contract is a Schedule to the ISDA Master Agreement in which parties can vary terms of the contract, agree financial thresholds which will trigger an Event of Default, select a governing law and many other contractual terms can be varied. The students saw how these documents worked in tandem and learned that typically a final piece of the contractual jigsaw is a "Confirmation" for each individual financial transaction, or product. The Confirmation contains specific transaction dates, settlement / payment dates, applicable rates such as EURIBOR and the signature of authorised personnel.

Introducing the students to the various clauses of the Master Agreement had many benefits, not least the fact that there are many boiler-plate clauses with which the students became familiar for the purposes of reviewing any contract. Our discussions helped them to revise issues around Events of Default, waiver terms and representations and warranties, all of which they had studied in Contract law modules.

Furthermore, the terms of the Agreement are so widely used that familiarity with them could only benefit anyone starting a career in a commercial firm, or other commercial law environment.

Finally, the discussion of ISDA's work brought us to considering the future of lawyers and law firms. The very fact of this achievement by ISDA in developing the Master Agreement and other documents opened their eyes to what might be required of lawyers more in the future. Sir Richard Susskind has opined that lawyers of the future 
will be expected to assist in achieving more of these efficient mechanisms of standardised contracts intra industry. ${ }^{4}$

\section{(iii) Understanding the risk management aspect ;" close-out netting"}

One of the key provisions within the ISDA Master Agreement is a mechanism for close-out netting. This is particularly important for banks trading with other banks, where the volumes of trade can be significant and the monetary amounts staggering. The contractual intent of close-out netting is that if a bank in another jurisdiction should fail, all transactions are valued and a contractual set-off is used to produce a net amount owed to, or from, the failed bank which is a party to the agreement. With wholesale financial transactions involving significant amounts, no bank wants to trade with a risk that, upon the liquidation of the counterparty bank, amounts owing may have to be paid out by the bank, while amounts owed to it might have to be proven by it as an unsecured creditor of that counterparty bank. This aspect of the Master agreement was particularly suitable for those final year students as they were also studying company law provisions on insolvency, restructuring (examinership/administration) and liquidation. The students were able to link this knowledge to their other course material and appreciated the context.

(iv) A real and widely used contract

\footnotetext{
4 Tomorrow's Lawyers, Susskind R. , Oxford University Press p.26
} 


\section{Practice Report}

While students study Contract law for at least a year, they do not always see and hold a contract. Bespoke contracts are not widely available and books of precedent did not form part of the University library's materials and subscriptions, so using the ISDA Master Agreement appealed to me as it offered the students something tangible and actual. I wanted them to see, and review, a document widely used internationally by large companies and financial institutions.

\section{The link to legal opinions by law firms}

ISDA also provides Legal Opinions to its members on the enforceability of close-out netting in various jurisdictions. Typically a leading firm in any given jurisdiction will be instructed by the Association to give a legal opinion on the likelihood that, in that jurisdiction, the courts and national laws would respect and uphold the close-out netting (contractual set-off) provisions in the Master Agreement. Members pay for those Legal Opinions and rely heavily on them when assessing their risk to a counterparty and to a particular jurisdiction. Banks will assess their risk to other financial institutions but the students were interested to learn that banks also assess their risk to countries, especially those which are not long-established, stable democracies. The ability of any country to secure a "clean" Legal Opinion is very important to the financial institutions in that jurisdiction. Counterparties and trading partners are easier to find if they don't bear the risk of your banks insolvency above and beyond the net amount owing between you at any given time. In many 


\section{Practice Report}

jurisdictions, legislation is passed to specifically uphold these close-out netting provisions in the contract.

\section{Laws and lobbying introduced}

Making that link from contract to Legal Opinion to legislation for the students enabled me to explain the genesis of many laws and explain why certain sectors of business have associations and lobby groups. The Irish Banking Federation played a role, for example, in highlighting to the Irish Government of the day the importance of adopting legislation to facilitate the certain application of "close-out netting". Legislative provisions were deemed necessary to confirm and ensure that the provisions of such a Master Agreement would be upheld and applied by a court in the event of the insolvency or liquidation of any Irish credit institution or Irish registered company.

The students learned how the need to ensure the contractual terms of the ISDA Master Agreement were upheld on insolvency led to the, lobbying for, and passing of legislation. The students also understood how the legislators therefore operated in an economic context and enacted the legislation to ensure the continuation of commerce with Irish financial institutions and large companies.

One of the interesting aspects this highlighted for the students was that the legislative process, which they had studied in first year, did not operate in a vacuum, rather that draft legislation responded often to the needs of individual or corporate citizens. 


\section{Legislation which is fit for purpose}

So the students scrutinised the Irish legislation - the Netting of Financial Contracts Act, 1995 - and wrote an explanatory memorandum on the need for, and effects of, the sections of that Act. This brought the issues into sharp focus for the students and they displayed a comprehensive understanding of the Netting of Financial Contracts Act, 1995 in the papers submitted by them to me.

\section{Pedagogic Reflections}

When seeking to identify a clinical legal education project I considered using my professional experience in this area for a couple of reasons. One reason was that aspiring commercial lawyers learning about financial products and how corporate clients use them is important. In addition, familiarity with the internationally used ISDA master agreement could only be beneficial to the students, the related legal opinion work of law firms and the links to national legislation really put law in context and connected each small financial transaction to the national issue of legislation. There is a chain of events and a series of consequences which becomes visible to the students.

While we tend to teach areas of law as separate and distinct subjects, or modules, in reality they merge and interconnect. The project based on the ISDA master agreement illustrated the connections between the business transaction and the contract. It also linked the contract terms to the issue of the legal opinion. The status of the close-out 
netting terms of the contract upon insolvency linked contract law and company law. The financial services sector needed to ensure the enforceability of the terms of the contract, which in turn linked the legislative process to the contract. All of these links were compatible with a deep learning experience. ${ }^{5}$

Using a real contract with the students is not unlike the use made by those teaching civil procedure of real accounts of cases. ${ }^{6}$ The compilation of the materials into a text with accompanying annotations may also be worth considering. That seems to have been done to great effect by Nan D. Hunter using the critical pleadings of the Paula Jones' sexual harassment case against President Clinton. ${ }^{7}$

In addition to giving the students more material on the financial products, I will enhance this project in the future either by including a guest lecture by a lawyer negotiating the master agreements on behalf of a large financial institution or by having the students simulate a_negotiation of the terms themselves. ${ }^{8}$

\section{Conclusion}

It was satisfying to organise a project in a way which gave the students an opportunity to amalgamate at least three areas of law which they had studied and to see those in a

\footnotetext{
${ }^{5}$ Reflection and assessment in clinical legal education:Do you see what I see ? Ledvinka G., Journal of Clinical Legal Education August 2006, p. 35

${ }^{6}$ Using a Simulated Case File to Teach Civil Procedure: The Ninety-Percent Solution Oppenheimer D. , Journal of Legal Education, Vol 65, number 4 (Summer 2016)

7 The Power of Procedure : The litigation of Jones v Clinton, Aspen Law \& Business (2002)

8 'Time to rework the brand 'Clinical Legal Education', Noone M.A., IJCLE (19) p. 345
} 
Practice Report

practical context. At another level the project gave the students a holistic approach to the issue of derivatives contracts in particular. While they could revise many areas of law already studied, they also got a $360^{\circ}$ view of the key legal issues in the capital markets - at least, as experienced by lawyers! 